\title{
CAVEAT EMPTOR AND THE SALE OF LAND: The Erosion of A Doctrine
}

\section{DON J. MANDERSChEID, Q.C.}

The author examines the doctrine of caveat emptor and the exceptions to this doctrine that the courts have recognized. In particular, the requirements for disclosure on behalf of the vendor are examined, especially in relation to latent defects in land. The author concludes that, with the increasing exceptions to caveat emptor, the doctrine may be headed toward $a$ rather limited and distinct application.
L'auteur examine la doctrine du "caveat emptor" et les exceptions à cette doctrine que les tribunaux ont reconnues. En particulier, l'obligation d'information au nom du vendeur y est examinée surtout dans le contexte de vice caché dans les terres. L'auteur conclut que, compte tenu du nombre grandissant d'exceptions au "caveat emptor". la doctrine semble être partie pour une application plutôt limitée et distincte.

\section{TABLE OF CONTENTS}

I. INTRODUCTION ................... 441

II. CAVEAT EMPTOR AND DEFECTS IN LAND $\ldots \ldots \ldots \ldots \ldots \ldots 443$

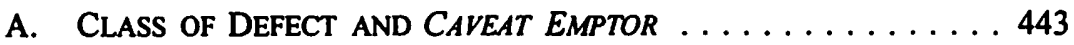

B. CAVEAT EMPTOR AND THE PURCHASER'S INSPECTION $\ldots \ldots 444$

III. LATENT DEFECTS AND THE VENDOR'S LIABILITY $\ldots \ldots \ldots \ldots \ldots 446$

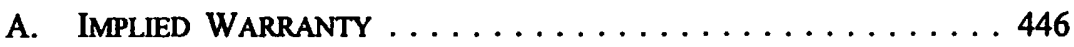

B. KNOWLEDGE AND DisCLOSURE $\ldots \ldots \ldots \ldots \ldots \ldots \ldots 48$

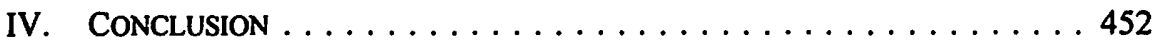

\section{INTRODUCTION}

For commerce to thrive there must be an element of certainty as to when a transaction is considered complete. ${ }^{1}$ This is particularly so with respect to the buying and selling of land where the rights of the vendor in the land must, at some point in time, be foreclosed in favour of those of the purchaser. The necessity for this legal closure was commented on in the nineteenth-century decision of Allen v. Richardson, ${ }^{2}$ where Malins V.C. stated:

I do not think there is a more important principle than that a purchaser investigating a title must know that when he accepts the title, takes the conveyance, pays his purchase-money and is put into possession, there is an end to all as between him and the vendor on that purchase. If it were otherwise, what would be the consequence? A man sells an estate generally because he wants the money; if this were not the rule, he must keep the money at his banker's, and there never would be an end to the question; whereas by adhering to the rule, the purchaser is put into possession at once of his land, and the vendor has the purchase-money to dispose of as he thinks fit the moment after receiving it. ${ }^{3}$

B.A., LL.B., LL.M. Legal counsel with the Law Branch, Corporate Services Department, City of Edmonton. This article reflects only the views of the author.

I See Redican v. Nesbitt, [1924] I D.L.R. 536 at 543-44 (S.C.C.) [hereinafter Redican], where Duff J. comments on the need for finality and certainty in business affairs and, in particular, in the conveyance of real property.

2 (1879), 13 Ch.D. 524 at 541 (Eng. Ch. Div.).

Ibid. at 541 . 
In response to this need for legal closure, the judiciary created the doctrine of law known as caveat emptor. ${ }^{4}$ By this doctrine, apart from an express warranty, contractual condition, collateral contract, fraud, or error in substantialibus, ${ }^{5}$ upon conveyance of title the purchaser is deemed to have acquired the land together with all attending infirmities and enhancements. ${ }^{6}$ Absent these exceptions, caveat emptor will prevent a purchaser from reopening the contract if, subsequent to conveyance, the purchaser concludes that the land does not have the quality that the purchaser assumed it had. In such a situation, any remedy that the purchaser may have against the vendor for defects related to the land must arise from the covenants in the sale agreement.'

In Redican Duff J., in describing the legal effect of caveat emptor relative to a completed sale of land, had this to say:

The whole point is: at what stage does caveat emptor apply?

The vendee may refy after completion upon warranty, contractual condition, error in substantialibus, or fraud. Once the conveyance is settled and the estate has passed, it seems a reasonable application of the rule to hold that as to warranty or contractual condition resort must be had to the deed unless there has been a stipulation at an earlier stage which was not to be superseded by the deed, as in the case of a contract for compensation. Bos v. Helsham (1866), L.R. 2 Ex. 72. Misrepresentation which is not fraudulent, and does not give rise to error in substantialibus, could only operate after completion as creating a contractual condition or a warranty. Finality and certainty in business affairs seems to require that as a rule, when there is a formal conveyance, such a condition or warranty should be therein expressed and that the acceptance of the conveyance by the vendee as finally vesting the property in him is the act which for this purpose marks the transition from contract in fieri to contract executed; and this appears to fit in with the general reasoning of the authorities. ${ }^{8}$

Caveat emptor is a creation of the judiciary - what the courts have created the courts can change. ${ }^{9}$ Accordingly, over time the judiciary has in certain instances intervened and limited the circumstances under which caveat emptor will apply. Most recently this judicial intervention has occurred where, after completion of the sale, the state of the land

See Black's Law Dictionary, 4th ed. s.v. "caveat emptor," where the term caveat emptor is defined as meaning "[1]et the buyer beware." See also Fraser-Reid v. Droumisekas, [1980] 1 S.C.R. 720 at 730 [hereinafter Fraser-Reid], where Dickson J. refers to the fact that the doctrine of caveat emptor is a creation of the courts.

See Holmes v. Walker (1997), 35 O.R. (3d) 699 at 703 (Gen. Div.), where Campbell J. defines the term "error in substantialibus": "Error in substantialibus translates badly into English. It does not mean substantial error. It means more. It means that the buyer and the seller made a mistake about some fundamental quality of the thing sold. It means an error in the very substance of what is sold, an error so fundamental that it goes to the real identity and character of the thing sold." Redican, supra note 1 at 543; Fraser-Reid, supra note 4 at 723.

Redican, ibid. at 541.

lbid. at 543-44.

See Fraser-Reid, supra note 4 at 730 , where Dickson J. states that as the doctrine of caveat emptor is a judicial creation, "what the courts created, the courts can delimit." 
is found to be uninhabitable or dangerous to persons or property. ${ }^{10}$ In these situations the judiciary has barred the application of coveat emptor on the justification that a vendor owes a duty to the purchaser to disclose those defects in the land that are known to the vendor and that could not have been identified through normal inspection by the purchaser. In this article the writer proposes to discuss the doctrine of caveat emptor in the context of the sale of land and, in particular, the effect of this judicial intervention visa-vis the continued application of the doctrine to sales of land.

\section{CAVEAT EMPTOR AND DEFECTS IN LAND}

\section{A. Class of Defect and CaVEat Emptor}

Defects affecting land fall into two classifications: those that are readily apparent to the eye and those that are not." "The former class of defect is considered patent and the latter latent. In Yandle \& Sons v. Sutton, Sargant J., in discussing the visual aspect associated with the distinction between patent and latent defects, stated:

In all these cases between vendor and purchaser, the vendor knows what the property is, and what the rights with regard to it are. The purchaser is generally in the dark. I think, therefore, that, in considering what is a latent defect and what a patent defect, ... which can be thrust upon the purchaser, [it] must be a defect which arises either to the eye, or by necessary implication from something which is visible to the eye. ${ }^{12}$

A determination of the application of caveat emptor will depend upon the classification of the defect. In the case of patent defects, lacking an express provision in the sale agreement, the vendor is not required to communicate to the purchaser defects that might affect a purchaser's judgment relative to the acquisition of the land. ${ }^{13}$ Accordingly, caveat emptor will apply to patent defects unless it can be shown that the vendor has intentionally concealed their presence. ${ }^{14}$ In contrast, a vendor must communicate to the purchaser all known latent defects. ${ }^{15}$ Consequently, as latent defects are unascertainable

See McGrath v. MacLean (1979), 95 D.L.R. (3d) 144 at 151 (Ont. C.A.) [hereinafter McGrath]; Tony's Broadloom \& Floor Covering Lid. v. NMC Canada Inc. (1996), 6 R.P.R. (3d) 143 at 151 (Ont. C.A.) [hereinafter Tony's Broadloom]. [1922] 2 Ch. 199 at 210 (Eng. Ch. Div.). See also 581244 Alberta v. Continental Mortgage Co. (1998), 21 R.P.R. (3d) 222 at 255 (Alta. Q.B.).

is See Jung v. Ip (1988), 47 R.P.R. 113 at 123 (Ont. Dist. Ct.) [hereinafter Jung]. 
through visual examination, ${ }^{16}$ caveat emptor will only apply provided their existence was unknown to the vendor at the time of sale. ${ }^{17}$

The application of caveat emptor relative to the particular class of defect was described by Solomon J. in Gronau as follows:

In other words, patent defects are those readily discoverable by ordinary inspection. Vendor is under no duty to draw attention to patent defects which can readily be observed by the purchaser if he pays ordinary attention during inspection. If the purchaser fails to observe patent defects on inspection he cannot be heard to complain about such defects later and the rule of caveat emptor applies. On the other hand, latent defects are those not readily apparent to the purchaser during ordinary inspection of the property he proposes to buy. If latent defects are actively concealed by the vendor, the rule of caveat emptor does not apply and the purchaser can, at his option, ask for rescission of contract and/or compensation for damages resulting therefrom. ${ }^{18}$

Although the ability to detect a defect by visual examination is a relevant consideration in determining classification, in certain cases, aside from the fact that the defect is not visible, the courts have regarded the defect as patent rather than latent. ${ }^{19}$ To complicate matters, as a defect's classification will be determined by its visible obviousness, under certain circumstances the classification may change due to the occurrence of a particular event. ${ }^{20}$ Hence, what may once have been a latent defect may at another time become visible and therefore be considered patent.

\section{B. CaVEat Emptor AND THE PURChaser's INSPECtion}

The fundamental precept of caveat emptor is that the onus is on the purchaser to ensure that the land to be acquired is in a state satisfactory for the purchaser's needs. ${ }^{21}$ Normally this onus is discharged through the purchaser's visual inspection of the land prior to completion of the sale..$^{22}$ Nonetheless, where the defect is obvious the courts

The form that a latent defect may take is legion and may vary from a crack in a wall (see Gronau v. Schlamp Investments Lid. (1974), 52 D.L.R. (3d) 631 (Man. Q.B.) [hereinafter Gronau]), to termite infestation (see Jung, supra note 15 at 123), to a buried culvert (see Jackson v. Pearldale Limited (1962), 47 M.P.R. 257 (N.S.C.A.) [hereinafter Jackson]), to a radioactive site (see Sevidal v. Chopra (1987), 45 R.P.R. 79 (Ont. S.C.) [hereinafter Sevidal]), to slope instability (see McCluskie v. Reynolds (1997), 19 R.P.R. (3d) 218 (B.C.S.C.) [hereinafter McCluskie]).

See Jaremko v. Shipp Corp. (1995), 47 R.P.R. (2d) 229 at 258 (Ont. Gen. Div.) [hereinafter Jaremko].

Supra note 16 at 636.

Tony's Broadloom, supra note 10 at 150.

See Davies v. Clarke (1995), 106 Man. R. (2d) 288 at 291 (Q.B.) [hereinafter Davies], where the Court dealt with a situation involving water seepage in a wall that was at one time considered as a latent defect but later, due to its obviousness, became a patent defect.

See Tony's Broadloom, supra note 10 at 150 . Here Doherty J. comments on the fact that what is considered a "defect" may not be open to strict definition. See also 801438 Ontario v. Badurina (2000), 34 R.P.R. (3d) 306 at 321(Ont. Sup. Ct.), where Himel J. comments that "what constitutes a defect in the quality of land must be determined in the context of the intended use of the land." Ward, supra note 11 at 287 . In this case Mandel D.C.J. held that defects in a floor could not only have been detected by a visual inspection but were also detectable having regard to the other senses, in that the floors creaked when walked upon. 
have required that in addition to conducting a visual inspection the purchaser must also make due inquiry as to the state of the land. ${ }^{23}$ As well, in certain cases the courts have required that in order to avoid caveat emptor a purchaser has an obligation to communicate to the vendor the particulars of the purchaser's proposed use of the land. ${ }^{24}$

In Tony's Broadloom Doherty J.A., in discussing the requirement for inquiry and communication of the intended use on the part of the purchaser, stated:

If I am wrong and the presence of the contaminant was a defect, I agree with the conclusion of White J. ... that the defect was a patent one. It would have been readily discoverable by the appellants had they exercised reasonable vigilance in the circumstances. In deciding whether the appellants exercised reasonable vigilance, it must be remembered that the appellants were buying industrial land on which they proposed to build a residential condominium. A reasonable inspection of the property, reasonable inquiries of the respondents, and reasonable inquiries of the local and provincial authorities would have put the appellants on notice of the existence of the contaminant. Indeed, had the appellants pursued the taking of soil samples with reasonable diligence after the respondents had permitted them to take those samples, they would have learned of the existence of the contaminant before closing. Instead, the appellants chose not to disclose their intended use of the property and to take no steps to satisfy themselves that the property could be used for that purpose. ${ }^{2 s}$

In conducting the requisite inspection the purchaser may or may not, depending upon the nature of the statement, be able to rely upon every statement made by the vendor as to the state of the land. ${ }^{26}$ For this reason, rescission of a contract will not be allowed where the statement is one founded on a mere opinion and where there is no representation of its correctness. ${ }^{27}$ Furthermore, statements made by a vendor that are termed in commercial circles as "puffing," 28 or "dealers' talk,"29 and that may have attributed to enticing the purchaser to enter into the bargain, may fall short of being characterized as a misrepresentation. Moreover, statements made in the course of social discussion and not for the purpose of advancing any particular commercial interest have

See Grossman Holdings Lid. v. Visplar Holdings Lid. (1976), 1 R.P.R. 40 at 45 (Ont. S.C.), where Holland J. held that where the defect was "obvious" (a sketch plan attached to the sale agreement showed a railway line that had the effect of splitting the land in two) the purchaser had a duty to inquire as to the nature of the defect prior to signing the sale agreement. Jackson, supra note 16 at 276 . In this case Currie J. held that there would only have been a duty upon the vendor to inform the purchaser as to the existence of a latent defect (underground culvert) in the land if the purchaser had advised the vendor of the purchaser's proposed use of the land. Supra note 10 at 150.

See Ferris v. Edwards (1919), 15 O.W.N. 361 at 362 (C.A.), where Feguson J.A. held that because the purchaser had inspected the land specifically for the purpose of ascertaining for himself the correctness of the vendor's statements, the purchaser could not then ask for rescission of the contract, alleging misrepresentations on the part of the vendor. See Cromwell v. Morris (1915), 23 D.L.R. 888 at 890 (Alta. S.C.) and Andronyk v. Williams, [1986] 1 W.W.R. 225 at 238 (Man. C.A.) [hereinafter Andromyk]. See Frost v. Stewart (1998), 19 R.P.R. (3d) 281 at 284 (Ont. Gen. Div.) [hereinafter Frost], where Hogg J. held that the description of the land in the listing went beyond what is termed "puffing." See also Andronyk, ibid., where O'Sullivan J.A. discusses the subject of "puffing." "dealers' talk" relative to representations made by a vendor as to the state of the land. 
been found not to be a misrepresentation. ${ }^{30}$ However, where a vendor's statement constitutes a representation that is material and induces the purchaser to acquire the land, and the representation is later found to be fraudulent, the purchaser may rescind the contract. ${ }^{31}$ In such cases the courts have stated that purchasers are under no duty to investigate the truthfulness of what they were told. ${ }^{32}$

As the cases bear witness, in order to stave off the unwanted effects of caveat emptor, mere reliance upon human senses and advice may not suffice. Thus the more prudent course may be for a purchaser to obtain from the vendor, through the sale agreement, an express warranty as to the state of the land and a requirement for full disclosure of all patent and latent defects relative to the land. ${ }^{33}$ In doing so, the purchaser shifts the onus to the vendor to ascertain and confirm that the state of the land will comply with the vendor's obligations to the purchaser under the sale agreement.

\section{LATENT DEFECTS AND THE VENDOR'S LIABILITY}

As mentioned previously, caveat emptor will not normally apply to latent defects associated with the land. ${ }^{34}$ Nevertheless, as with any doctrine of law, there are exceptions. ${ }^{35}$ The number of these exceptions may not remain static and are prone to change in response to societal circumstancesunder which the doctrine of law is to operate. Consequently, what may have been appropriate at the time of the industrial revolution may have no application in today's modern world with its antecedent legacy of environmental contamination.

In the case of caveat emptor there are two notable additional exceptions. The first involves the sale of residential dwellings and the imposition of an implied warranty of habitability. The second is concerned with situations where the vendor, having knowledge of the existence of a latent defect affecting the land, fails to disclose this knowledge to the purchaser prior to completion of the sale.

\section{A. IMPLIED WARRANTY}

Unlike the sale of goods, in the ordinary course of the buying and selling of land, without an express warranty or contractual provision in the sale agreement, the law will not imply a warranty as to the merchantability of the land for purposes of habitation. ${ }^{36}$

See C.P.R v. Aitken (1916), 10 W.W.R. 1052 at 1055 (Alta. C.A.), where Scott J. held that statements made by the agent of a company to "a friend in the course of social intercourse, not for the purpose of advancing the company's interests ... but merely for the purpose of giving that friend what is commonly known as a 'tip,"' did not constitute a misrepresentation.

${ }^{31}$ See Allen v. McCutcheon (1979), 9 R.P.R. 191 at 195 (B.C. S.C.) [hereinafter Allen].

$32 \quad$ Ibid.

33 See Brownlie v. Campbell (1880), 5 App. Cas. 925 at 949 (H.L.), where Lord Selbome L.C. held that the onus is on the purchaser to determine the degree of warranty that should be obtained from the vendor.

See Part I where the exceptions to the doctrine of caveat emptor are dicussed.

McGrath, supra note 10 at 153. 
However, there is one area of land sales where such a warranty will be implied: the sale of a residential dwelling that is incomplete in terms of construction.

Where, at the time that the purchase and sale commitment is made, the construction of a residential dwelling has not been completed, there is imposed by law on the builder/vendor, in favour of the purchaser, a requirement that the work will be carried out in "an efficient and workmanlike manner, be of proper materials," and that the dwelling will be fit for its intended purpose: habitation. ${ }^{37}$ Because the law imposes this implied warranty, it will be interjected into the bargain concluded under the sale agreement, unless excluded by express words to that effect in that agreement. ${ }^{38}$ In determining whether a dwelling is habitable, the courts have held that continued possession by the purchaser is indicative of habitability. ${ }^{39}$

Although a welcome protection for the homebuyer, this implied warranty has one major drawback: it is limited in its scope of application to sales involving uncompleted residential dwellings and will therefore not apply to all land sales. For this reason caveat emptor will remain applicable to the sale of a used or completed residential dwelling. ${ }^{40}$ As well, caveat emptor will continue to apply where the purchaser acquires a residential dwelling in an incomplete condition on the express agreement that the purchaser will complete the required construction. ${ }^{41}$

Where the residential dwelling is used, it is understandable to prohibit the imposition of the implied warranty because the vendor, not being the original owner or perhaps having a short duration of ownership, may have no knowledge as to the condition of the structure. ${ }^{42}$ However, from a purely pragmatic perspective, there would appear to be no basis for the irrationality that exists between the law applicable to a completed as opposed to an uncompleted residential dwelling. In Fraser-Reid Dickson J., in commenting on this irrationality, made the following statement:

At the same time, it must be observed that the decided English and Canadian cases in this area point up the irrationality and odd results derived from the rigid "completed/incomplete" distinction. Take the case of the prospective home buyer who views a model home in a sub-division development and decides to buy a house yet to be built on a lot in that subdivision. In his case, the courts will be willing to imply a warranty as to fitness for habitation and workmanship. But the unfortunate who buys the "show" home

See Rawson v. Hammer (1982), 19 Alta. L.R. 22 at 25 (Q.B.) [hereinafter Rawson], where Legg J. refers to the judgment in Miller v. Cannon Hill Estates Ltd., [1931] 2 K.B. 113 as authority for this proposition. See also Strata Plan NW2294 v. Oak Tree Construction Inc. (1994), 93 B.C.L.R. 50 at 52 (C.A.) [hereinafter Strata Plan].

$38 \quad$ Strata Plan, ibid. at 53.

39 See Wong v. $\mathrm{Ng}$ (1998), 16 R.P.R. (3d) 136 at 145 (B.C. S.C.).

to See Scott-Polson v. Hope (1958), 14 D.L.R. (2d) 333 at 337 (B.C. S.C.), where Maclean J. held, in a case involving a used residential dwelling, "there is no implied warranty that a residential property is fit for human habitation." See also Strata Plan, supra note 37 at 52, where Lambert J.A. discusses the law relative to the question of when a residential dwelling is considered complete.

Rawson, supra note 37 at 26.

See Klassen v. Gerlitz, [1954] 3 D.L.R. 377 at 377-78 (B.C. S.C.) [hereinafter Klassen], where Wood J. took into account the fact that the defendant vendor had owned the 40-year-old house for just over two years and had no knowledge as to its state (dry rot). 
is without warranty even if both models reveal the same structural defects. Or, take the case of the buyer who enters into a contract for a home that is "99 per cent complete". The courts will imply a warranty: Perry v. Sharon Development Co. Lid. Had the contract been entered into the next day, when the work was completed, there is no warranty. One can easily multiply the incongruities. ${ }^{3}$

The justification for the continuance of this implied warranty continues to be the subject of criticism by the judiciary..$^{44} \mathrm{Be}$ that as it may, it is generally accepted that the elimination of the discrepancy associated with this implied warranty is not within the purview of the courts and is best left to the legislature. ${ }^{45}$

\section{B. KNOWLEDGe AND DisClosure}

\section{MANNER OF DISCLOSURE}

Depending on the circumstances caveat emptor may have no application where a vendor has knowledge of a latent defect connected with the land and fails to impart this knowledge to the purchaser prior to completion of the sale. ${ }^{46}$ In these instances fraud on the part of the vendor or those persons to whom the vendor is responsible at law will dissipate the defence of caveat emptor. ${ }^{47}$ Furthermore, liability may be found where, although not fraudulent, the vendor is reckless in failing to divulge this knowledge to the purchaser ${ }^{48}$ In $\mathrm{McCl}$ luskie Bennett $\mathrm{J}$., while discussing the application of caveat emptor to these two particular situations, had this to say:

In conclusion, I find that although the law of vendor and purchaser has long relied on the principle of caveat emptor to distribute losses in real estate cases, the rule is not without exception. Two major exceptions are in the case of fraud, and in cases where the vendor is aware of latent defects which he

Supra note 4 at 729-30 [footnotes omitted].

4 See McCluskie, supra note 16 at 233, where Bennett J. concedes that "[d]espite the illogical basis for the distinction, the existence of this implied warranty still very much depends upon whether the house is completed or not."

Strata Plan, supra note 37 at 53. See also Fraser-Reid, supra note 4 at 730-31, where Dickson J. concludes that the "removal of the irrational distinction between completed and incomplete houses is better left to legislative intervention" and that "the complexities of the problem, the difficulties of spelling out the ambit of a court-imposed warranty, the major cost impact upon the construction industry and, in due course, upon consumers through increased house prices, all counsel judicial restraint." Please note that presently the only Canadian provinces that have passed such legislation are Ontario with the Ontario New Home Warranties Plan Act, R.S.O. 1990, c. 0.31 and British Columbia with the Homeowner Protection Act, S.B.C. 1998, c. 31. It is interesting to note that in Alberta, although there is no statute similar to that of Ontario's and British Columbia's, pursuant to s. 14(c) of the Residential Tenancies Act, R.S.A. 1980, c. R-15.3 there is an implied covenant in every residential tenancy agreement "that the premises will be habitable by the tenant at the beginning of the tenancy." Unfortunately the statute neither defines the term "habitable," nor does it give any guidelines relative to the implied covenant. Sevidal, supra note 16 at 101-102.

47 Jung, supra note 15 at 123. See also B. Laskin, "Defects of Title and Quality: Caveat Emptor and the Vendor's Duty of Disclosure" in Law Society of Upper Canada Special Lechures (Toronto: Richard De Boo, 1960) 389 at 404, where the late Bora Laskin C.J.S.C. stated that "fraud can be a rather elastic conception." 
does not disclose. The law also supports the imposition of a duty to disclose latent defects on the vendor where he is not subjectively aware of those defects, but where he is reckless as to whether or not they exist. It is up to the plaintiff to prove this degree of knowledge or recklessness.9

Should a vendor remain silent or conceal a latent defect associated with the land, the conduct of the vendor will be considered as constituting a fraud on the purchaser in the form of deceit. ${ }^{50}$ Where fraud is established, rescission of the contract will be allowed. ${ }^{51}$ Nonetheless, not every failure by the vendor to disclose latent defects pertinent to the land will constitute fraud. While a misrepresentation is usually associated with a verbal statement, the failure to divulge relevant information will also be considered in determining liability. ${ }^{52}$ In cases involving misrepresentation once the contract is complete, unless the misrepresentation is fraudulent or results in an error in substantialibus, rescission will not be available to the purchaser. ${ }^{53}$

\section{DUTY OF CARE}

Without actual knowledge as to the presence of latent defects related to the land a purchaser must rely upon the vendor to advance this knowledge. In an endeavour to lessen the adverse effects that may flow from latent defects associated with land, the judiciary has imposed a duty of care on the vendor vis-d-vis the purchaser regarding the state of the

Ibid. at 229.

See Lerke v. Brear (1990), 78 Alta. L.R. (2d) 24 at 38 (Q.B.); Allen, supra note 31 at 195; Frost, supra note 28 at 284; Gronau, supra note 16 at 636-37; and Rawson, supra note 37 at 27-28. Contra Pelletier v. St-Laurent (1996), 14 R.P.R. (3d) 112 (Qc. C.A.). In this case the Court held that in the absence of lies or fraudulent manoeuvres on the part of the vendor, the vendor will not be held liable for its silence, as the vendor is not obliged to disclose every event that occurred during its ownership; the evidence showed that a previous flood was an isolated event and that the vendors' obligation did not extend to force them to reveal such an occurrence.

Gronau, supra note 16 at 637 ; Allen, supra note 31 at 195; and see generally Sevidal, supra note 16 at 97.

See McCluskie, supra note 16 at 231 , where Bennett J. comments that in certain circumstances the absence of a statement can amount to a negligent misrepresentation.

See Clancy v. Shanahan (1997), 9 R.P.R. (3d) 55 at 63 (Nfld. T.D.), where Green J. discusses the past and present judicial views on the topic of rescission of a contract. See also Thurston v. Streilen, [1951] 4 D.L.R. 724 at 728 (Man. K.B.) and Keen v. Alterra Developments Led. (1993), 35 R.P.R. (2d) 278 at 283 (Ont. Gen. Div.), where Fedak J. discusses the law related to a party's right to have the contract rescinded. Whether or not rescission is an available remedy will be determined on the basis of the contract being "executory" as opposed to "executed." In this respect, where the contract is considered "executed," rescission will only be allowed for a misrepresentation that is not fraudulent where, as a result of the misrepresentation, it can be proven that there exists an error in substantialibus or a contractual condition or warranty. Where the contract is considered as executed rather than executory, should the misrepresentation be considered innocent, caveat emptor will apply and the purchaser is without remedy either in the form of rescission or a claim to damages. In this respect, see Jaremko, supra note 17 at 259; Bryson v. Egerton (1999), 25 R.P.R. (3d) 113 at 132-33 (B.C. S.C.); and Schonekess v. Bach (1968), 62 W.W.R. 673 at 676 (B.C. S.C.). In terms of innocent misrepresentation, the pertinent law is set out quite succinctly in Kingu v. Walmar Ventures L\&d. (1986), 10 B.C.L.R. (2d) 15 at 20-21 (C.A.). For negligent misrepresentation see McCluskie, supra note 16 at 230. 
land ${ }^{54}$ As a consequence of this duty of care, a vendor is required to disclose to the purchaser the existence of all known latent defects affecting the land. ${ }^{55}$ This disclosure requirement will continue until the date of conveyance of the title to the land. ${ }^{56}$ In imposing this duty of care, the judiciary transcends the bounds of any contractual liability that the vendor may have under the sale agreement ${ }^{57}$ and will hold the vendor liable in tort. $^{58}$

In certain circumstances the obligation of disclosure may take the form of a warning by the vendor to the purchaser as to the existence and possible harmful effects of the latent defect. ${ }^{59}$ This is particularly the case where the latent defect has or may have the potential of creating a danger to persons or property by rendering the land uninhabitable or dangerous in itself. In McGrath Dubin J.A., in discussing these two particular scenarios, stated:

I am prepared to assume that, in an appropriate case, a vendor may be liable to a purchaser with respect to premises which are not new if he knows of a latent defect which renders the premises unfit for habitation. But, as is pointed out in the lecture above referred to, in such a case it is incumbent upon the purchaser to establish that the latent defect was known to the vendor, or that the circumstances were such that it could be said that the vendor was guilty of concealment or a reckless disregard of the truth or falsity of any representations made by him. It is to be observed that that is quite a different case than the one founded on the principle of $M^{\prime}$ Alister (or Donoghue) v. Stevenson, supra.

Similarly, 1 am prepared to assume that there is a duty on the vendor to disclose a latent defect which renders the premises dangerous in themselves, or that the circumstances are such as to disclose the likelihood of such danger, e.g., the premises being sold being subject to radioactivity. Again, however,

Because the writer is unaware of any special standard of care pertaining to situations involving the failure to disclose latent defects related to land, it is submitted that the standard of care should be that used in the typical negligence case, being that of the "reasonable person." See Queen v. Cognos Inc. (1993), 99 D.L.R. (4th) 626 at 651 (S.C.C.) [hereinafter Cognos].

Jung, supra note 15 at 123 . It should be noted that this disclosure requirement is not to be confused with any statutory disclosure obligation on the part of the vendor. In this respect, in Alberta s. 99 of the Environmental Protection and Enhancement Act, S.A. 1992, c. E-13.3 provides that "[t]he person having control of a substance that is released into the environment that has caused, is causing or may cause an adverse effect shall, immediately on becoming aware of the release," report the release to any "person who the person reporting knows or ought to know may be directly affected by the release." Contra Klassen, supra note 42 at 379 , where at one time the Court was of the opinion that "[t]here is no implied duty on the owner of a house which is in a ruinous and unsafe condition to inform a proposed tenant that it is unfit for [human] habitation."

Sevidal, supra note 16 at 102 . In this case Oyen J. held that where the vendor became aware of a latent defect in the land (presence of radioactive material) between the time of the signing of the sale agreement and the closing, the vendor had a duty to disclose the change of circumstances to the purchaser prior to closing.

Tony's Broadloom, supra note 10 at 151 . Here Doherty J.A. states that the duty to warn is separate from any contractual liability that the vendor may have under the sale agreement.

See Hansen v. Twin City Construction Co., [1982] 4 W.W.R. 261 at 266 (Alta. Q.B.) [hereinafter Hansen], where Feehan J. discusses the aspect of tort liability stemming from the negligence of a home builder and that individual's duty of care to potential purchasers. See also Buthmann v. Balzer (1983), 26 Alta. L.R. (2d) 122 at 132-33 (Q.B.) [hereinafter Buthmann], where Dea J. provides a list of cases where contract and tort law have overlapped. 
under such circumstances the cause of action is not dependent on the principles enacted in M'Alister (or Donaghue) v. Stevenson. ${ }^{60}$

The rationale for this duty of care lies in the existence of a sufficient relationship of proximity between the vendor of land and the purchaser. ${ }^{61}$ Due to this relationship, it is assumed that it is within the reasonable contemplation of the vendor that, if the vendor acts in a manner that is considered careless towards the purchaser, the purchaser may incur damages. ${ }^{62}$ Should a vendor breach this duty of care, caveat emptor will not prevent recovery by the purchaser as against the vendor for damages incurred. In these situations liability will be imposed not simply because the vendor had actual knowledge as to the presence of the latent defect; liability can also be based on the fact that the vendor ought to have known of the existence of the latent defect. ${ }^{63}$

Owing to this duty of care and the requirement to hold a vendor accountable, irrespective of the fact that the vendor may have no actual knowledge as to the existence of the latent defect, the vendor is placed in the precarious position of guarantor vis-à-vis the state of the land. In such a position, the vendor must now not only insure that the purchaser is fully aware of all latent defects affecting the land, whether known or unknown, but also of the repercussions associated with each. Where this duty of care exists, it is now the vendor, as opposed to the purchaser, who must seek protection in the provisions of the sale agreement. ${ }^{64}$ It would, therefore, appear that as a consequence of

Supra note 10 at 151-52.

61 See McCluskie, supra note 16 at 230-31, where Bennett J., in quoting Lambert J.A. in Edgeworth Construction Led. v. N.D. Lea \& Associates Lid. (1991), 53 B.C.L.R. (2d) 180 (B.C. C.A.), reiterates that such a duty arises from "foreseeability, reliance and proximity," with proximity bearing the heaviest burden in the decision-making process. Contra Cognos, supra note 54 at $647-48$, where Iacobucci J. discusses the proper test to be used in determining when a "special relationship" exists between the parties such as to give rise to a duty of care. In Cognos Iacobucci J., in reference to Caparo Industries plc v. Dickman, [1990] 1 All E.R. 568 (H.L.), stated that in that case the House of Lords suggested that "three criteria determine the imposition of a duty of care: foreseeability of damage; proximity of relationship, and the reasonableness or otherwise of imposing a duty."

See Anns v. Merton London Borough Council, [1978] A.C. 728 at $751-52$ (H.L.) [hereinafter Anns], where Lord Wilberforce in determining whether or not a duty of care existed between the contracting parties developed a two-stage analysis based, firstly, on the establishment of a proximity of relationship and, secondly, on the negating of any policy considerations that serve to limit the scope of the duty of care, "the class of person to whom it is owed or the damages to which a breach of it may give rise." For a discussion of the Canadian decisions that have adopted the two-stage analysis in Anns see Martel Building Lid. v. Canada, [2000] 2 S.C.R. 860. See also Buthmann, supra note 58 at 129.

63 See Davies, supra note 20 at 291 , where Kennedy J. held that the vendor was liable to the purchaser for a latent defect, given that the vendor knew of the latent defect or ought to have known of the latent defect and had a duty to fully disclose the nature of the latent defect to the purchaser. See also Jung, supra note 15 at 129 . Contra Buthmann, supra note 58 at 130, where Dea J. commented that he was unaware of any decision where a duty of care had been imposed upon a tortfeasor to warn where the tortfeasor had "no knowledge of the defect and the defect itself does not constitute a dangerous situation."

See Toffoli v. Rozenhart (1992), I Alta. L.R. (3d) 104 at 109 (Q.B.), where Funduk M.C. held that where the purchaser acquired the land with an express provision in the sale agreement that the property was being sold on an "as is" basis, concurrent liability in tort would not be permitted so as to allow the purchaser to circumvent a contractual exclusion for the act that constitutes the tort. 
this duty of care, the roles of vendor and purchaser have been reversed with the ultimate result being the replacement of the doctrine of caveat emptor with the doctrine of caveat venditor. ${ }^{65}$

\section{Conclusion}

In Fraser-Reid Dickson J. commented on the fact that "[a]lthough the common law doctrine of caveat emptor has long since ceased to play any significant part in the sale of goods, it has lost little of its pristine force in the sale of land." may have been applicable at that particular time, from the previous discussion it is evident that since then the doctrine of caveat emptor has and continues to be eroded from its original application to sales of land. For the most part, this erosion is due to the reaction of the judiciary to changing times. ${ }^{67}$ As a result, more and more exceptions to the doctrine have and continue to be created. Of these exceptions the most significant relate to latent defects associated with the land.

As the jurisprudence germane to the doctrine of caveat emptor becomes one more of exception than distinction, it is foreseeable that at some point in time the doctrine may be limited in its application to situations involving clearly ascertainable patent defects in the land. When and if this occurs, the doctrine itself may cease to play any meaningful role in the sale of land, and the irrational distinction that presently exists between the law applicable to sales of personal property and real property may be considered redundant. ${ }^{68}$ Nevertheless, until this transpires the doctrine must be dealt with as it continues to evolve. To this end, it is hoped that the foregoing discussion may be of some assistance.

See Black's Law Dictionary, supra note 4, where the term caveat venditor is defined as meaning "a maxim, or rule, casting the responsibility for defects or deficiencies upon the seller of goods." The definition goes on to state that in English and American jurisprudence "[c]aveat venditor is sometimes used as expressing, in a rough way, the rule which governs all those cases of sales to which caveat emptor does not apply." Supra note 4 at 723.

67 It should be noted that in certain jurisdictions the doctrine of caveat emptor has, if anything, been bolstered by the passage of legislation that creates the potential for a present owner of land to be responsible for the contaminated state of the land. In these situations, liability will be imposed by the statute, notwithstanding that the owner may have recently purchased the land and was unaware at the time of purchase as to the existence of the contamination. This is the case in Alberta, where pursuant to s. $96(1)(c)$ of the Environmental Protection and Enhancement Act, supra note 55, the "person responsible for the contaminated site" is defined as including the present owner of the contaminated land and any previous owner. There would appear to be no correlation between liability for the contamination and being the actual perpetrator who released or caused the release of the hazardous substance. In accordance with s. 96(1)(c), liability will be imposed based purely on ownership of the land. In these situations caveat emptor could never be more applicable.

Hansen, supra note 58 at 267-68. 